\title{
ANALISIS KESULITAN SISWA SMA NEGERI 1 KEDUNGWUNI MATERI LOGARITMA
}

\author{
Istifada Nurul Hayati ${ }^{1}$ Budiyono $^{2}$ \\ ${ }^{1,2}$ Universitas Sebelas Maret Surakarta
}

\begin{abstract}
During the process of mathematics learning, problem solving is one of the important factors in influencing the success of mathematics learning. The objective of this study is determining students' difficulties in understanding logarithm functions. It is also intended to find out alternative solutions in overcoming the problems. The form of this research is a qualitative descriptive study using Spradley model data analysis through research procedures from Sudjana publication book. Based on preliminary observations, students' mathematics problem solving skill at SMAN 1 KEDUNGWUNI has various ways. The number of students of class X MIPA 3 SMAN 1 Kedungwuni 1 is 32 students. $25 \%$ of students have high problem-solving skill, whereas $75 \%$ have low problem-solving skill. The cause of the problem is derived from teachers, students, and learning tools. Students' mistakes in solving some tasks related to logarithm functions material become obstacles in the next learning process. The written test analysis results and interviews results of students regarding their difficulties in solving logarithm function include: students tend to have low understanding related to initial concepts of logarithm functions, students have difficulty in understanding the application of logarithm functions, and they find a difficulty in applying it into task in the form of story. Alternative solutions that can be implemented to deal with these problems are building the concept of logarithm functions from the previous chapter, namely root and exponent, emphasizing the concept of logarithm functions by giving related tasks, and practicing more tasks about logarithm functions.

Keywords:Analysis, Mathematics, Logarithms, Roots, Exponents.
\end{abstract}

\section{PENDAHULUAN}

Matematika sebagai ilmu dasar, dewasa ini telah berkembang dengan pesat baik materi maupun kegunaannya, sehingga dalam pembelajaran di sekolah harus memperhatikan perkembangan, baik di masa lalu, masa sekarang maupun untuk masa depan. Sepanjang kegiatan belajar mengajar siswa dengan guru ada kecenderungan tidak terdapat kesungguhan dan kegembiraan belajar, tidak terjadi penyerapan materi ajar secara baik dan benar, akibatnya mata pelajaran matematika tidak dikuasai sebagaimana mestinya bahkan mereka tidak tahu atau salah penggunaanya. Kesulitan belajar dilapangan dapat dilihat masalahnya seperti tidak ada dorongan untuk siswa aktif belajar.

Pemecahan masalah dalam proses pembelajaran matematika merupakan salah satu faktor yang penting dalam mempengaruhi keberhasilan pembelajaran matematika. Melalui pemecahan masalah, siswa dapat memahami masalah dari soal yang ada dengan benar. Selain itu mampu merencanakan dan menyelesaikan cara penyelesaiannya. Siswa diharapkan untuk dapat memecahkan masalah matematika tersebut, sehingga akan berdampak pada ingatan siswa tentang materi pelajaran yang diajarkan. Keterlibatan siswa dalam melakukan langkah-langkah pembelajaran dapat mempertajam ingatan 
tentang materi pelajaran. Dengan demikian, sekolah perlu meningkatkan keterampilan pemecahan masalah siswa dalam belajar.

Berdasarkan pengamatan awal, keterampilan pemecahan masalah matematika di Sekolah Menengah Atas (SMA) Negeri 1 Kedungwuni sangat bervariasi. Siswa kelas X MIPA 3 SMA Negeri 1 Kedungwuni berjumlah 32 siswa mempunyai kemampuan keterampilan pemecahan masalah yang tinggi hanya 25\% dan yang rendah sebanyak 75\%. Pemecahan masalah dalam belajar matematika diamati dari indikator Alfeld (Widjajanti, 2009) antara lain: (1) mampu memahami masalah, (2) merumuskan penyelesaian masalah, (3) penyelesaian masalah sesuai rencana, (4) penafsiran hasil. Jika menurut Setiyawan (2016), masalah yang perlu menjadi perhatian berkaitan dengan pelajaran matematika adalah banyaknya kesalahan yang dilakukan siswa dalam menyelesaikan soal-soal matematika, sedangkan menurut Malau (Sahriah, 2012) penyebab kesalahan yang sering dilakukan siswa dalam memecahkan soal-soal matematika dapat dilihat dari beberapa hal antara lain disebabkan kurangnya pemahaman atas materi prasyarat maupun materi pokok yang dipelajari, kurangnya penguasaan bahasa matematika, keliru menafsirkan atau menerapkan rumus, salah perhitungan, kurang teliti, dan lupa konsep. Penelitian Mahmuda (Sulistyarini, 2016) dengan judul diagnosis kesalahan siswa menyelesaikan soal bentuk pangkat, akar dan logaritma menunjukkan bahwa kesalahan yang dilakukan siswa dalam menyelesaikan soal bentuk pangkat, akar, dan logaritma terdiri dari kesalahan konseptual dan kesalahan prosedural. Akar penyebab permasalahan keterampilan pemecahan masalah bersumber dari guru, siswa, dan peralatan belajar.

Pada observasi lapangan yang dilakukan peneliti di SMA Negeri 1 Kedungwuni, pada tingkat SMA masih banyak siswa yang masih melakukan kesalahan dalam menyelesaikan soal-soal pada materi logaritma. Masih banyak siswa tidak selesai mengerjakan dikarenakan tidak memahami langkah pengerjaan yang menggunakan sifat logaritma. Hal ini mungkin disebabkan karena operasi pada logaritma berbeda dengan operasi pada bilangan real maupun bilangan bulat yang telah dikenal siswa waktu SMP. Kesalahan-kesalahan dalam menyelesaikan soal tentang materi logaritma menjadi hambatan dalam proses pembelajaran selanjutnya. Banyak kesalahan yang dilakukan oleh siswa dalam menyelesaikan soal-soal matematika. Oleh karena itu, perlu dilakukan analisis mengenai kesulitan siswa dalam materi logaritma untuk mengetahui bentuk dan penyebab kesalahan siswa, sehingga guru dapat menerapkan langkah yang tepat untuk memberi bantuan kepada siswa. 
Berdasarkan latar belakang, maka rumusan masalahnya adalah: (1) apa saja kesulitan yang menjadikan siswa kurang memahami materi logaritma? (2) bagaimana alternatif solusi dari masalah yang terjadi? Adapun tujuan dari penelitian ini untuk mengetahui kesulitan yang menjadikan siswa kurang memahami materi logaritma dan untuk mengetahui tentang alternatif solusi dari masalah yang terjadi. Hasil penelitian ini diharapkan mampu memberikan manfaat baik secara teoritis maupun praktik: (1) mampu memberikan jawaban atas kesulitan yang dihadapkan pada siswa SMA materi logaritma serta membuka kemungkinan untuk penelitian yang lebih lanjut tentang permasalahan yang sejenis, (2) sebagai bahan kajian yang dapat dimanfaatkan untuk bahan evaluasi karena masih banyak siswa tidak paham materinya, (3) dapat memberikan masukan tentang solusi dari permasalahan mengenai materi logaritma untuk kemudian ditindak lanjuti sehingga pembelajaran selanjutnya menjadi lebih baik, (4) mendorong siswa untuk meningkatkan kemampuan belajarnya dengan memahami tentang hal yang belum mereka pahami dan yang mereka anggap sulit.

\section{METODE PENELITIAN}

Penelitian ini berlokasi di SMA Negeri 1 Kedungwuni Kabupaten Pekalongan karena didasarkan pada pertimbangan bahwa sekolah tersebut mempunyai konotasi dalam penilaian pembelajaran yang baik sehingga akan dilakukan penganalisisan pembelajaran pada sekolah tersebut. Peneliti mengambil dari siswa SMA Negeri 1 Kedungwuni kelas X MIPA 3 sebanyak 3 subjek yang dijadikan sampel peneliti karena menurut peneliti melakukan penelitian semacam ini dibutuhkan kedekatan emosional antara peneliti dan subjek,supaya data yang diambil lebih akurat. Kedekatan emosional merupakan kemampuan seseorang mengenali emosi diri dan orang lain dengan karakteristik bisa memahami, dapat dipercaya, membuat orang yang diajak komunikasi merasa nyaman sehingga dapat membuat mereka lebih terbuka dengan apa yang mereka permasalahkan tentang mata pelajaran matematika khususnya materi fungsi logaritma, dengan begitu peneliti memilih 3 subjek tersebut dengan keterangan Subjek pertama (S1), Subjek kedua (S2) dan Subjek ketiga (S3).

Bentuk penelitian ini merupakan penelitian deskriptif kualitatif. Penelitian kualitatif adalah penelitian yang bermaksud untuk memahami fenomena tentang apa yang dialami oleh subjek penelitian, misal perilaku, persepsi, motivasi, tindakan, dan lain-lain, secara holistik (utuh) dan dengan cara deskripsi dalam bentuk kata-kata dan bahasa, pada suatu konteks khusus yang alamiah dan dengan memanfaatkan berbagai metode alamiah (Moleong, 2009: 6). Tujuh langkah penelitian kualitatif menurut Sugiyono (2010: 284) 
ditunjukkan sebagai berikut: (1) membangun kerangka konseptual, (2) merumuskan permasalahan penelitian, (3) pemilihan sampel dan pembatasan penelitian, (4) instrumentasi, (5) pengumpulan data, (6) analisis data, dan (7) matriks serta pengujian kesimpulan. Prosedur penelitian ini dengan mengikuti langkah Sudjana (2001) sebagai berikut: (1) mengidentifikasi masalah, (2) pembatasan masalah yang dalam penelitian kualitatif sering disebut fokus penelitian, (3) penetapan fokus penelitian, (4) pengumpulan data, (5) pengolahan dan pemaknaan data, dan (6) pemunculan teori, (7) pelaporan hasil penelitian.

Setelah semua data terkumpul, maka langkah selanjutnya adalah pengelolahan dan analisa data atau proses mencari dan menyusun secara sistematis data yang diperoleh dari hasil wawancara, catatan lapangan, dan dokumentasi, dengan cara mengorganisasikan data ke dalam kategori, melakukan sintesa, menyusunnya ke dalam pola, memilih mana yang penting dan akan dipelajari, serta membuat kesimpulan. Analisis data dalam penelitian ini menggunakan analisis data kualitatif, jadi dalam analisis data selama di lapangan peneliti menggunakan model spradley, yaitu teknik analisa data yang di sesuaikan dengan tahapan dalam penelitian (Sudjana, 2001), (1) memilih tempat, subjek, dan aktifitas, (2) menetapkan subjek yang merupakan informan, berwibawa dan dipercaya dapat membantu peneliti dalam melalakukan penelitian, (3) kemudian peneliti melakukan pengambilan data dengan memberikan soal materi logaritma dengan dikerjakan subjek dan diamati oleh peneliti secara langsung, (4) setelah subjek selesai mengerjakan soal tersebut, peneliti melakukan analisis jawaban subjek, (5) penganalisisan selesai, peneliti melakukan wawancara kepada subjek tersebut, dan mencatat hasil wawancara yang dilakukan, (6) selanjutnya peneliti menuliskan laporan penelitian kualitatif.

\section{HASIL DAN PEMBAHASAN}

A. Hasil dan Analisis

Hasil penelitian analisis terhadap jawaban tes tertulis dan hasil wawancara dengan siswa mengenai kesulitan mereka dalam menyelesaikan soal-soal bentuk logaritma yang telah dijelaskan dalam bentuk soal dan jawaban

1. Hasil tindakan pada subjek yang pertama (S1)

a. Hasil jawaban

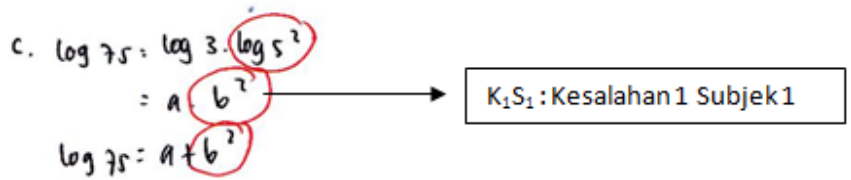




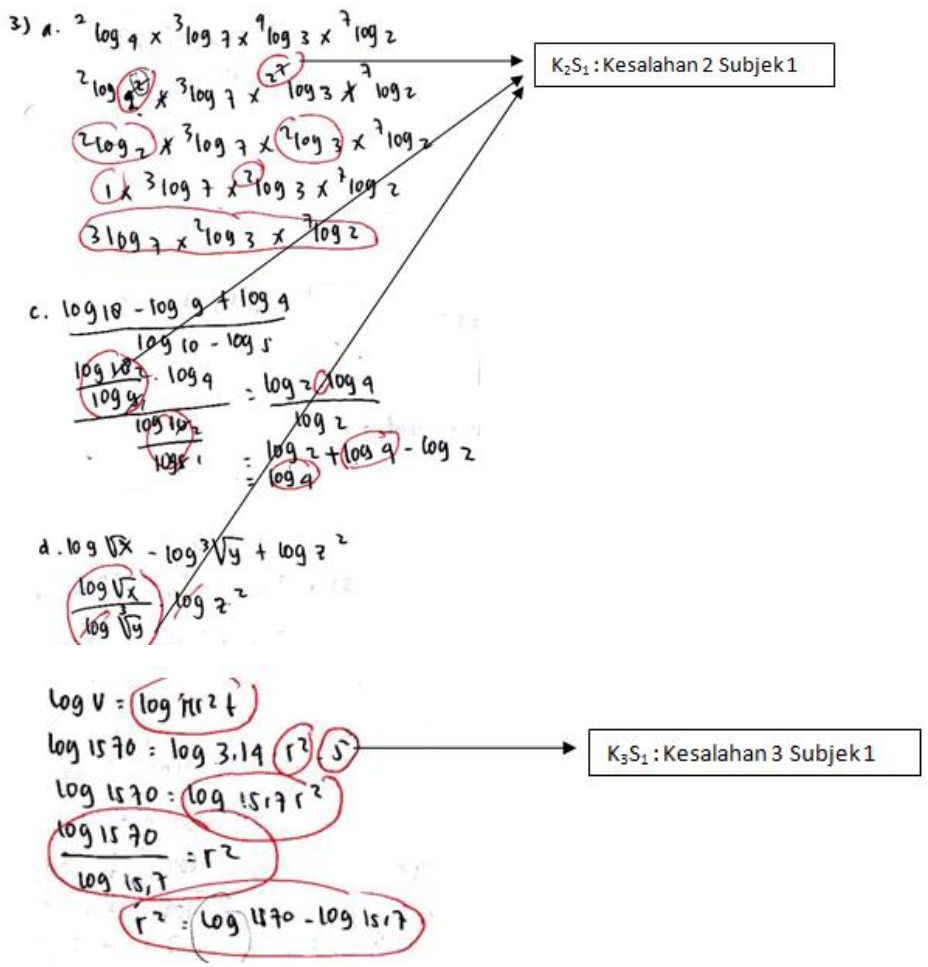

b. Analisa

Pada $K_{1} S_{1}$ soal no 2c diperoleh bahwa $S_{1}$ mengalami kesalahan yaitu kurang cermat dalam mengubah sifat logaritma kebentuk operasi pangkat. Pada hasil jawaban $S_{1}$ belum paham dalam menyelesaikan soal sehingga melakukan operasi pangkat seperti sifat eksponen bukan menggunakan sifat logaritma.

Pada $\mathrm{K}_{2} \mathrm{~S}_{1}$ soal no 3a, c dan d diperoleh bahwa $\mathrm{S}_{1}$ mengalami kesalahan yaitu melakukan kesalahan saat mengubah sifat logaritma yang bersifat perkalian dan pembagian. Pada hasil jawaban $S_{1}$ belum hafal dengan sifat logaritma yang ada dalam soal sehingga $S_{1}$ menyelesaikannya dengan cara menerka-nerka hasil pemikiran sendiri tanpa menggunakan teori yang sudah ada sehingga mengakibatkan kesalahan sampai akhir jawaban.

Pada $K_{3} S_{1}$ soal no 5 diperoleh bahwa $S_{1}$ mengalami kesalahan yaitu melakukan kesalahan saat mengubah soal cerita kebentuk sifat logaritma. Pada hasil jawaban $S_{1}$ tidak pernah mencoba soal logaritma yang berupa soal cerita sehingga mengakibatkan kesalahan sampai akhir jawaban.

Berdasarkan hasil jawaban siswa dan pembahasan hasil analisa jawaban siswa maka dirumuskan solusi alternatifnya untuk mengatasi permasalahan tersebut adalah membangun konsep fungsi logaritma dari bab sebelumnya yaitu akar dan pangkat sangat membantu siswa untuk mengenal definisi logaritma terlebih dahulu dengan penerapan kebalikan fungsi 
perpangkatan atau yang disebut logaritma sebagai invers dari pangkat, selain itu bisa dengan memberikan contoh yang sudah ada atau contoh yang siswa sudah pahami kemudian dikembangkan kembali.

c. Hasil Wawancara

Berdasarkan hasil wawancara dengan subjek pertama (S1) dapat disimpulkan bahwa S1 kebingungan dalam menerapkan sifat-sifat logaritma kedalam soal. Kesalahan yang dilakukan S1 terjadi karena kurang paham konsep sifat-sifat logaritma sehingga S1 mengerjakan dengan sebisanya.

2. Hasil tindakan pada subjek yang kedua (S2)

a. Hasil jawaban

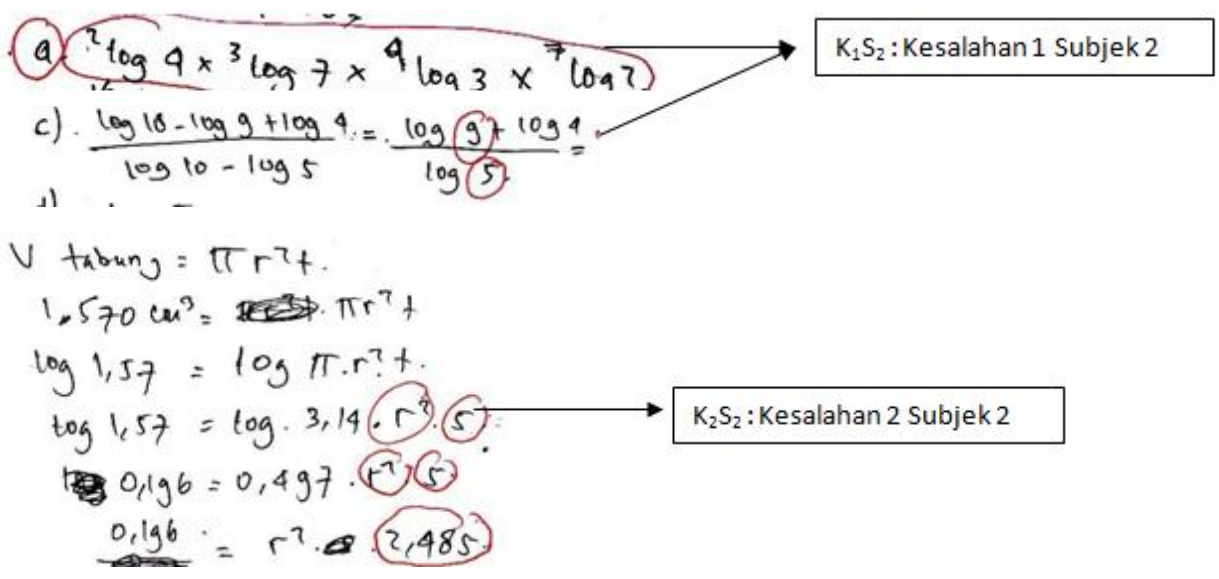

b. Analisa

Pada $\mathrm{K}_{1} \mathrm{~S}_{2}$ soal no 3a dan c diperoleh bahwa $\mathrm{S}_{2}$ mengalami kesalahan yaitu melakukan kesalahan saat mengubah sifat logaritma yang bersifat perkalian dan pembagian. Pada hasil jawaban $S_{2}$ tidak paham dengan sifat logaritma yang ada dalam soal sehingga $S_{2}$ tidak menyelesaikannya sampai akhir jawaban.

Pada $\mathrm{K}_{2} \mathrm{~S}_{2}$ soal no 5 diperoleh bahwa $\mathrm{S}_{2}$ mengalami kesalahan yaitu melakukan kesalahan saat mengubah sifat logaritma pada soal cerita kebentuk sifat logaritma yang bersifat perkalian. Pada hasil jawaban $\mathrm{S}_{2}$ lupa dengan mengubah sifat logaritma tersebut sehingga mengakibatkan kesalahan sampai akhir jawaban.

Berdasarkan hasil jawaban siswa dan pembahasan hasil analisa jawaban siswa maka dirumuskan solusi alternatifnya untuk mengatasi permasalahan tersebut adalah lebih menekankan konsep tentang sifat-sifat 
logaritma dengan cara diberikan soal yang berkaitan dengan sifat-sifat logaritma tetapi tiap sifat logaritma harus terdapat perubahan disetiap tanda operasi hitung yang digunakan. Pada konsep mengubah bilangan pokok logaritma point-point penting perlu diperhatikan kembali sehingga siswa tidak kesulitan membedakannya.

c. Hasil Wawancara

Berdasarkan hasil wawancara dengan subjek kedua (S2) dapat disimpulkan bahwa S2 dapat memahami konsep logaritma, terbukti S2 dapat menerapkan definisi logaritma kedalam soal, akan tetapi masih kesulitan dalam menerapkan untuk sifat-sifat logaritma.

3. Hasil tindakan pada subjek yang ketiga (S3)

a. Hasil jawaban

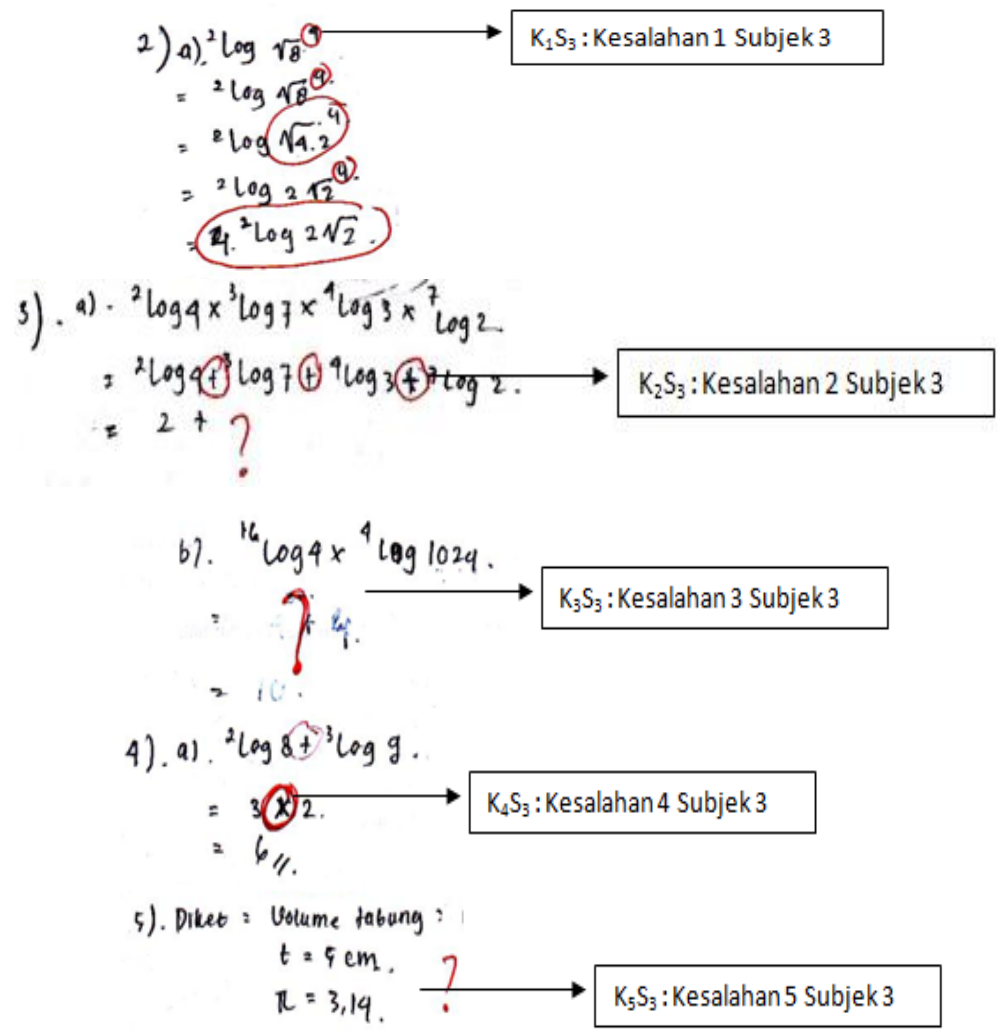

b. Analisa

Pada $\mathrm{K}_{1} \mathrm{~S}_{3}$ soal no 2a diperoleh bahwa $\mathrm{S}_{3}$ mengalami kesalahan yaitu melakukan kesalahan saat menghitng operasi perpangkatan pada sifat logaritma. Pada hasil jawaban $\mathrm{S}_{3}$ salah memahami soal sehingga $\mathrm{S}_{3}$ tidak dapat menyelesaikannya dengan benar.

Pada $\mathrm{K}_{2} \mathrm{~S}_{3}$ soal no 3a diperoleh bahwa $\mathrm{S}_{3}$ mengalami kesalahan yaitu melakukan kesalahan saat mengubah sifat logaritma yang bersifat perkalian 
dan pembagian. Pada hasil jawaban $S_{3}$ kurang paham dengan sifat logaritma tersebut sehingga sehingga $S_{3}$ tidak dapat menyelesaikannya dengan benar.

Pada $\mathrm{K}_{3} \mathrm{~S}_{3}$ soal no 3 b diperoleh bahwa $\mathrm{S}_{3}$ mengalami kesalahan. Pada hasil jawaban $\mathrm{S}_{3}$ tidak paham dengan sifat logaritma yang ada di soal sehingga $\mathrm{S}_{3}$ tidak menyelesaikan soal.

Pada $\mathrm{K}_{4} \mathrm{~S}_{3}$ soal no 4a diperoleh bahwa $\mathrm{S}_{3}$ mengalami kesalahan yaitu melakukan kesalahan saat mengubah tanda operasi hitung penjumlahan. Pada hasil jawaban $S_{3}$ kurang teliti dengan sifat logaritma tersebut sehingga sehingga $\mathrm{S}_{3}$ tidak dapat menyelesaikannya dengan benar.

Pada $\mathrm{K}_{5} \mathrm{~S}_{3}$ soal no 5 diperoleh bahwa $\mathrm{S}_{3}$ mengalami kesalahan. Pada hasil jawaban $\mathrm{S}_{3}$ tidak pernah mencoba soal logaritma yang berupa soal cerita sehingga $\mathrm{S}_{3}$ tidak menyelesaikan soal.

Berdasarkan hasil jawaban siswa dan pembahasan hasil analisa jawaban siswa maka dirumuskan solusi alternatifnya untuk mengatasi permasalahan tersebut adalah memperbanyak latihan soal-soal yang tekstruktur tentang sifat-sifat logaritma supaya siswa menjadi terbiasa dan paham dalam penerapan untuk tiap sifat logaritma. Mencoba, mencari dan mengerjakan soal mengenai soal cerita fungsi logaritma.

c. Hasil Wawancara

Berdasarkan hasil wawancara dengan subjek ketiga (S3) dapat disimpulkan bahwa S3 tidak memahami konsep logaritma, terbukti S3 menyelesaikan soal tanpa memperhatikan langkah-langkah dalam penyelesaian, kesalahan S3 terletak pada sistematis suatu penyelasaian.

\section{B. Pembahasan Analisa}

Hasil penelitian ini, berdasarkan analisis terhadap jawaban tes tertulis dan analisis terhadap hasil wawancara dengan siswa mengenai kesulitan mereka dalam menyelesaikan soal-soal bentuk logaritma yang telah dijelaskan sebelumnya, maka dapat diuraikan sebagai berikut:

1. Kesulitan pada subjek yang pertama (S1)

Subjek 1 cenderung kurang memahami konsep awal tentang sifat-sifat logaritma itu sendiri. Padahal untuk langkah mengerjakan matematika hal yang paling utama adalah memahami konsep, misalnya soal ulangan yang diberikan oleh guru tidak akan sama persis dengan soal yang dijadikan sebagai contoh dan seringkali siswa mengeluhkan hal tersebut karena soal ulangan tidak semudah contoh yang 
diberikan, padahal kenyataannya hanya angka saja yang diganti tetapi model soal masih sama hal itu dikarenakan siswa tidak memahami konsep.

2. Kesulitan pada subjek yang kedua (S2)

Subjek 2 masih banyak kebingungan pada penerapan sifat-sifat logaritma yang ada karena alasan banyaknya sifat-sifat logaritma tersebut, seringkali siswa berpendapat bahwa sifat-sifat logaritma harus dihafalkan padahal justru itu pendapat yang keliru jika menurut peneliti, karena banyak atau sedikitnya rumus jika kita memahaminya pasti tidaklah sulit untuk mengerti penerapannya jadi tidak perlu dihafalkan tetapi dipahami saja untuk setiap sifat logaritma.

3. Kesulitan pada subjek yang ketiga (S3)

Subjek 3 mengalami kesulitan dalam memahami konsep awal tentang sifat-sifat logaritma. Padahal kesalahan konsep merupakan kesalahan mendasar yang sangat fatal dikarenakan kesalahan ini dapat menimbulkan kesalahan lainnya yaitu kesalahan hitung serta kesulitan jika fungsi logaritma diterapkan dalam soal cerita. Seringkali siswa malas membaca soalnya terlebih dahulu atau bahkan tidak paham dengan apa yang dimaksud dalam bacaan soal cerita tersebut sehingga fungsi logaritma diterapkan dalam soal cerita membuat siswa mengalami kesulitan.

\section{SIMPULAN DAN SARAN}

Dalam penelitian, pengambilan kesimpulan sangatlah penting karena dapat menggambarkan penelitian. Sesuai dengan tujuan awal penelitian ini adalah untuk mengetahui kesulitan yang menjadikan siswa kurang memahami materi logaritma dan untuk mengetahui tentang alternatif solusi dari masalah yang terjadi. Berdasarkan hasil analisis dan pembahasan hasil analisis, maka dapat ditarik kesimpulan bahwa:

1. Kesulitan yang dihadapi subjek pertama yaitu mengenai kurangnya siswa memahami konsep teori sifat-sifat logaritma.Solusialternatifnya untuk mengatasi permasalahan tersebut adalah membangun konsep fungsi logaritma dari bab sebelumnya dan memberikan contoh yang sudah ada atau contoh yang siswa sudah pahami kemudian dikembangkan kembali

2. Kesulitan yang dihadapi subjek kedua yaitu kekeliruan siswa dalam menerapkan konsep teori sifat-sifat logaritma pada soal yang disajikan.Solusialternatifnya untuk mengatasi permasalahan tersebut adalah lebih menekankan konsep tentang sifat-sifat logaritma dengan cara diberikan soal yang berkaitan dengan sifat-sifat logaritma tetapi tiap sifat logaritma harus terdapat perubahan disetiap tanda operasi hitung yang digunakan. 
3. Kesulitan yang dihadapi subjek ketiga yaitu pemahaman siswa pada soal cerita yang sangat kurang, misal dari segi malas membaca soal yang panjang karena berbentuk soal cerita, tidak mengetahui maksud dari soal cerita itu sendiri atau bahkan guru tidak membahasnya ketika dikelas juga menjadikan dampak pada kesulitan yang dihadapi siswa. Solusialternatifnya untuk mengatasi permasalahan tersebut adalah memperbanyak latihan soal-soal yang tekstruktur tentang sifat-sifat logaritma supaya siswa menjadi terbiasa dan paham dalam penerapan untuk tiap sifat logaritma.

Cara untuk dapat mengurangi kesulitan pada subjek petama (S1), subjek kedua (S2) dan subjek ketiga (S3)dengan memberikan contoh soal logaritma yang sudah ada, kemudian dikembangkan ke contoh yang lain atau contoh yang baru supaya siswa memperhatikan perbedaannya, sehingga konsep tersebut akan selalu diingat siswa. Soal yang disajikan mungkin lebih kompleks supaya benar-benar tahu dalam hal mana yang di anggap siswa sulit, misalnya dalam suatu soal cerita yang terdapat gabungan dari beberapa sifat-sifat logaritma.

\section{DAFTAR PUSTAKA}

Kemendikbud. (2013). Matematika untuk SMA kelas X. Jakarta: Kementerian Pendidikan dan Kebudayaan.

Moleong, L., J. (2009). Metodologi Penelitian Kualitatif: Edisi Revisi. Bandung: Remaja Rosdakarya.

Sahriah, S. (2012). Analisis Kesalahan Siswa dalam Menyelesaikan Soal Matematika Materi Operasi Pecahan Bentuk Aljabar Kelas VIII SMP Negeri 2 Malang. Jurnal Matematika UM, 87 (1), 665-698.

Setiyawan, B. (2016). Analisis Kesalahan dalam Menyelesaikan Soal Logaritma pada siswa kelas X SMK N 1 Banyudono Tahun 2015/2016. Jurnal Of Research and Advances in Matematika Education, 1 (2), 2503-2529.

Sudjana. (2001). Penelitian dan Penilaian. Bandung: Sinar Baru.

Sugiyono. (2010). Metode Penelitian Pendidikan, Pendekatan Kuantitatif, Kualitatif dan $R \& D$. Bandung: Alphabeta.

Sulistyarini, D., A. (2016). Analisis Kesulitan Siswa SMK Citra Medika Sukoharjo dalam Menyelesaikan Soal Bentuk Akar dan Alternatif Pemecahannya. Konferensi Nasional Penelitian Matematika dan Pembelajarannya (KNPMP), 2016 (3), 605614.

Widjajanti, D., B. (2009). Proceeding Seminar Nasional Kemampuan Pemecahan Masalah Matematis Mahasiswa Calon Guru Matematika: Apa dan Bagaimana Mengembangkannya. Yogyakarta: FMIPA Universitas Negeri Yogyakarta. 